\title{
NATURE-BASED EDUCATION IN THE PROCESS OF IMMIGRANT INTEGRATION. THE CASE OF SWEDEN
}

\author{
Monika Banaś \\ Jagiellonian University in Krakow (POLAND)
}

\begin{abstract}
The Nordic countries, among them Sweden, were among the most popular destinations for refugees over the past decade. From the beginning of the so-called migration crisis, since 2015, Sweden received nearly 218,000 asylum applications. ${ }^{1}$ This number should be seen in the context of the entire Swedish population of some 10.2 million, $18.5 \%$ of which are former immigrants and their second and third generation descendants born already in Sweden. ${ }^{2}$ Contemporary Nordic societies, due to the migration processes, changed their ethnic compositions, becoming multicultural and multiethnic. Over the past 50 years the Nordic states and other non-state entities including NGOs co-shaping the social, economic, political and cultural order have been trying to develop integration policies aiming to include immigrants effectively into the mainstream society. Proposed solutions concerned primarily quick introduction of immigrants into the labour market and in the social and cultural life of the host country. However, not all solutions proposed as part of the integration policies have been successful. Most of them did not put enough emphasis on the sphere of education. Currently, a modified form of integration policies makes the educational aspects more visible and prominent. The article focuses on the most important solutions within the Nordic educational systems, which aim to accelerate and facilitate integration of immigrants. The subject is discussed in detail based on an example from Sweden where a specific type of education was developed heavily relying on the relationship and interactions between humans and nature/natural environment. This unusual way of teaching introduced into the educational practice in Sweden and other Nordic countries attracts significant attention among academics and politicians. It provides evidence which allows proposing a hypothesis that it is indeed a highly effective new approach to education and integration.
\end{abstract}

Keywords: integration, immigrants, nature-based education, Sweden.

\section{INTRODUCTION}

The Scandinavian countries, including Sweden experienced increasing immigration waves for several decades $(1990$ - 2015). This was caused not only by turbulence in world politics, resulting in the mass migration of people from areas subject to armed conflicts (including Eritrea, Somalia, Iraq, former Yugoslavia), but also by the specificity of national labor markets. The societies of the Scandinavian countries (and, more broadly, the Nordic countries) did not provide enough workforce since the mid1950s, which caused regular imports of foreign labor, first from continental Europe (e.g. Italy, Greece), then also from outside Europe ( e.g. Turkey) [1], [2], [3]. The 1990s marked by many armed conflicts, including the Balkan war or the war in Iraq, launched a massive escape of people from areas affected by the death spectrum. Sweden then adopted one of the largest refugee groups, mainly from Iraq and Somalia [4], [5]. Also today, with the ongoing conflicts in the Middle East, Sweden is accepting refugees, thus showing a far-reaching empathy for those in need [6], [7].

As a result of the processes of inflow of ethnically alien populations, Sweden continued changing its mono-ethnic character which as a country it used to have some 100 years ago. Today its population consists of many ethnic, racial, linguistic and religious groups, and is an example of a multicultural society of which $18.5 \%$ are immigrants [8].In such a diverse population in terms of ethnicity, it becomes a serious challenge to build communal unity, so much needed for efficient functioning of society, both in a collective and individual dimension. So how to build an integrated, multicultural community, whose components, although different, coexist and operate in harmonious manner? This question, and a challenge, has become the guiding principle for integration policy pursued by Sweden over the past decades. The main assumption of the integration policy implemented in Sweden since the 1960s (with some modifications over decades) was the principle that the parties involved, both the receiving party

\footnotetext{
${ }^{1}$ http://www.migrationsinfo.se/migration/sverige/asylsokande-i-sverige/ (retrieved: $30^{\text {th }}$ Oct. 2018).

${ }^{2}$ http://www.migrationsinfo.se/fragor-och-svar/hur-manga-utrikes-fodda-sverige/\#fn-38-1 (retrieved: $30^{\text {th }}$ Oct. 2018).
} 
and the incoming party, were partners. This policy tried to avoid the approach typical of other countries receiving immigrants, like Germany, France or Italy, where foreigners looking for jobs were referred to as Gastarbeiters, i.e. those who come, carry out the contracted work and leave after the contract. The reality has however verified that assumption.

It turned out that the so-called Gastarbeiters, after many years of residence in the host country, did not plan to return to their country of origin, as assumed by the authors of immigration policies in Germany, France or Italy. Thus, the problem arose as to how the population of culturally, ethnically, linguistically or religiously different groups should be included in the mainstream society [9], [10], [11]. Sweden, by adopting the partnership approach in its integration policy, tried to emphasize the symmetry of the autochthon - newcomer / immigrant relationship. In this symmetry an element of equality of indigenous people and immigrants, especially in the sphere of culture, ethnic language or religion was assumed. Immigrants received support from the state - institutional and financial - to cultivate their own culture, traditions, religion, etc. Partnership and respect for diversity became the main characteristic of Sweden's integration policy. Perhaps this is why Sweden is currently the highest ranking country on the Migrant Integration Policy Index (MIPEX). ${ }^{3}$

However, attention should also be paid to the weaknesses of the Swedish integration policy towards immigrants. Despite its high effectiveness, there are still areas in which the integration process is slower, weaker or unsatisfactory. Examples are provided by Swedish cities such as Stockholm, Södertälje, Örebro or Malmö, where in some immigrant districts levels of unemployment and crime are high and schooling rates are low [12], [13], [14]. Thus, the Swedish integration policy, modified under the influence of challenges provided by social practice, becomes a dynamic area - continuous conceptual and organizational work, also requiring adequate financial support. One of the latest solutions to increase the effectiveness of integration policy towards immigrants is nature-based education. It assumes the use of environmental education for faster and more efficient integration of immigrants into the mainstream society. Its assumptions and specific examples are discussed below.

\section{METHODOLOGY}

The methodology used in the research, results of which are presented in this text, consisted of five components: 1) a critical analysis of the literature on the Swedish migration and integration policies in the context of other Scandinavian countries and also in the wider international context, 2) an analysis of reports and publications issued by: IOM - International Organization for Migration, Migration Policy Institute, IMISCOE - International Migration, Integration and Social Cohesion, OECD - Organization for Economic Cooperation and Development, 3) an analysis of the Swedish government documents, official announcements from the parliament and other entities responsible for implementing integration policy in Sweden, 4) an analysis of existing materials concerning the Nordic ORIGIN project (Outdoor recreation, nature interpretation and integration in Nordic countries) funded by the Nordic Council of Ministers to use nature-based education in integration of immigrants, 5) study visits in the cities with a high percentage of immigrants (Malmö, Örebro and Växjö), accompanied by in-depth interviews with representatives of municipalities and immigrant communities (June - September 2018).

\section{RESULTS}

The main assumptions of the Swedish integration policy until 2015 can be characterized in the following points: 1) partnership taking into account cultural differences - this means that immigrants have the right and thus the conditions provided by the state for cultivating their own culture, language, traditions, religion and customs; 2) provision of state financial and institutional support in the process of acculturation and adaptation to live and work in the Swedish society according to different patterns that determine individual and collective interactions and different sets of values; 3 ) important role of regional and local institutions such as municipalities in the integration process - they are directly responsible for implementation of integration activities, including the labor market, education and civic engagement, or activation of immigrants in the social and political spheres (in the latter case at local and regional level) [15], [16], [17].

As mentioned above, integration policy is a dynamic matter, subject to modifications enforced by reality, which verifies approaches, tools, organizational and financial solutions. After 2015, which was characterized by an exceptionally high number of refugees, Sweden was forced to revise the existing

\footnotetext{
${ }^{3} \mathrm{http}: / /$ www.mipex.eu/sweden (retrieved: $6^{\text {th }}$ Jan. 2019).
} 
integration practices. In the context of the intense influx of immigrants, especially refugees and asylum seekers, it was necessary to critically evaluate the mechanisms that were to be used for integration. Thus, subject to verification were the mechanisms present on the labor market (procedures for integrating immigrants into the labor market, job placement, assessment of professional qualifications, etc.), in housing (allocation to regions and districts of residence, quality and size of housing, financial capacity to pay for housing), in education and schooling (evaluation of competences and skills). In the latter sphere, attention was drawn to the under-utilization of the potential of schools and universities in the integration process. This notion led to the launch of a special project carried out jointly by four Nordic countries: Norway, Denmark, Finland and Sweden. The project titled ORIGIN - Outdoor Recreation, Nature Interpretation and Integration in Nordic Countries, pays special attention to the use of nature as means through which the integration process can take place faster and more efficiently.

\subsection{Origin and integration}

ORIGIN - Outdoor Recreation, Nature Interpretation and Integration in Nordic Countries was a project implemented in 2016 - 2018 and funded by the Nordic Council of Ministers. The aim of the project was to explore the use of nature to help integrating immigrants into the host society. Nature in the tradition of the Nordic countries plays a very important role not only for ecological but also psycho-social reasons - it is one of the main factors shaping the Nordic identity [18]. For these reasons, it was recognized that education based on activities taking place in the bosom of nature, about nature, how it affects man and how man and other creatures function in it, can be a great way of integrating immigrants into receiving societies. Getting to know society and its culture through nature is here an example of the innovative use of available resources - in this case nature, previously not seen as one of the integration fields / spheres. The project, implemented in two stages, involved private, state and non-governmental organizations that deal with integration issues on a daily basis [19].

In the first stage of the project 127 questionnaire interviews were conducted with the actors directly involved in working with immigrants (persons representing state and private entities, NGOs as well as scientists dealing with integration issues). Interviews were aimed at gathering basic knowledge about the practice of using nature education in the integration of immigrants in four Nordic countries: Norway, Denmark, Sweden and Finland. In the second stage of the project, a one-day workshop was organized to discuss the collected material, formulate conclusions and recommendations for further work and research in this area. One of the main conclusions of the workshop (Helsinki 2016) was to verify the effectiveness of nature-based education in the process of migrant integration through social practice [20].

Another conclusion was related to the rather vague and imprecise definition of the term "nature-based integration". It turned out that it is not understood equally by the persons participating in the study and the participants of the workshop. An attempt to conclude was made during the next workshop (Copenhagen 2017), which proposed the following: "(...) nature-based integration; in a natural environment. Its basic pillars are building up identity empowering the migrant to be part of the local society. " [21]. In view of such an understanding of the term, one should pay attention to key elements defining / specifying nature-based integration: 1) this phenomenon is a process, 2) it is an engagement involving both parties - accepting and receiving, 3 ) it involves nature, learning about it, communing with it and through, learning about other people - autochthons and other immigrants, 4) it provides new experiences helping in building an individual identity of participants, 5) it serves to acquire new ones and develop already existing competences and skills to function in a new social, cultural, economic, political reality, etc.

Attention should be paid to the very term "integration". It replaced "assimilation" and "adaptation" commonly used in scientific, social and political discourse back in the 1990s [22], [23], [24]. Integration means the process of an active, committed attitude of both parties: the host society and the newcomers. It occurs first at the individual level and then at the community level. It includes spheres concerning 1) social structure (labor market, education, health care); 2) culture (values, customs, tradition); 3) identification (sense of belonging to a place); and 4) interaction i.e. social, friendly, neighborly relationships, etc. [25]. The information collected in the ORIGIN research allows us to make a cautious hypothesis that the use of nature is an effective way of invoking the above types of integration [26]. It should be emphasized that nature-based education contains many different curricula due to the target groups - recipients of this education. Curricula are not fully developed yet, because this is just the beginning of using environmental education to help integrate immigrants into the host society. At the moment, four main target groups can be distinguished: women, children and youth, adults and people with special needs (people with physical and mental dysfunctions). Such a division into groups seems 
too general and seems to omit other important diversifications, such as that between children and adults with mental and / or physical dysfunctions. For them the same didactic offer loses meaning, because the perception of a child and an adult differ. Therefore, in order to take full advantage of the innovative approach of the nature-based education, a more detailed customization for potential recipients should be developed, paying special attention to their distinctive needs.

\subsubsection{Forest as an integrating environment}

An activity initiated by the Swedish University of Agricultural Sciences (Sveriges Lantbrukuniversitet SLU), based in Uppsala, near Stockholm provides an example of a project oriented towards the integration of newly arrived immigrants. One of the programs developed there by an expert team composed of university staff was financially and organizationally supported by the Dorotea municipality and the board of the Västerbotten county, Västerbotten country board and the upper secondary school for agriculture in Burträsk, and consisted of regular educational meetings on forest and its resources. The participants in the course, mainly men and, to a much lesser extent, women - immigrants with already granted residence permits, took part in classes oriented not only to learn about the specifics of the Swedish nature, but also about the language which is used to describe it. Lessons on the Swedish language relevant for forest and forestry constitute one of the key educational elements in this program.

Apart from free language classes, so-called SFI (Svenska for invandrare) i.e. Swedish for immigrants, implemented by municipalities as part of a nationwide integration policy, in this case participants receive additional classes from a more specialized topic related language, helpful in searching for work in forestry. This additional opportunity to acquire further language and vocational skills is aimed at facilitating the entry of immigrants quickly into the labor market [27], [28].

A similar objective has another project developed by the Rural Economy and Agricultural Societies West and the Swedish Employment Service. It is directed strictly to facilitate people to work in forestry, by encouraging immigrants to pay attention to nature and the potential contained in it. In addition to the language course, participants take part in classes on Swedish fauna and flora, protection of natural assets, sustainable development, management of forest potential, logging and wood processing, etc. Examples of classes in the course include: Green Card, Brush cutter education, Chain saw education, Theory indoors, Theory and practice outdoors, Information about the labor and working environment, Insight into starting own business [29], [30].

The quoted courses and language classes are aimed not only at familiarizing newcomers with a new, often diametrically different natural environment from that native to the immigrants, but also at creating favorable conditions for personal and professional development [31]. In programs oriented at communing with nature, in this case with the forest, the soothing effect of the natural environment in its natural and not human modified version is particularly emphasized. Sweden, like the other Nordic countries, attaches great importance to the least possible human interference in the natural world. It results from the philosophy and culture of the countries of the far north, where degradation of the natural environment is perceived as the same as human degradation. Such a view, or conceptualization of nature as an element or co-determinant of individual and community identity, is most often foreign to immigrants coming primarily from dysfunctional countries. In countries damaged by armed conflicts or other catastrophes, the priorities are different than in countries with full prosperity.

The Nordic countries, which are among the best developed in the world, with a high HDI rating, have the possibility and means to protect and preserve nature. They have developed the practice of consciously using these resources in a sustainable way. Newcomers through nature-based education become acquainted with the principles and values that build common prosperity. This process, as indicated by the Swedish experience, is most effective when started as soon as possible, not long after the immigrant has arrived in the country. Meanwhile, nature-based education courses are addressed to people who have previously received a residence permit. It should be noted that the waiting time for a decision to grant or refuse the right of residence usually lasts for several months, and is usually productively idle. Therefore, to improve the management of time, human potential and work, integration courses using nature should be implemented earlier.

\subsubsection{Small businesses and immigrant entrepreneurship}

Integration as a complex and multistage process requires time, patience, but also well-organized and well-structured actions delivered by the host country, which should create favorable conditions for immigrants inclusion into the mainstream society. Besides, successful integration requires a positive 
attitude of both sides: the incoming and the hosting. One of the paths to integration can be established by small entrepreneurship, which immigrants can undertake without major administrative restrictions.

The Swedish law provides convenient opportunities for individuals willing to start and run their own business. Specialized courses offering basic knowledge in the area of small business are financed by municipalities, and third parties (e.g. NGOs) are invited to co-organize such classes. An example of a successful integration project based on small entrepreneurship is provided by a network of small grocery stores run by a married couple from the Middle East who came to Sweden in the 1990s. As refugees, they had been given basic financial and psychological assistance from the state, as well as the opportunity to participate in Swedish language course for beginners (SFI) and courses covering basic knowledge about the Swedish state and society. Unfortunately, these courses were not attractive enough for the couple, who after a short time resigned from participating in this kind of education. The courses seemed a "waste of time" for people who wanted to obtain economic self-dependency avoiding living on social benefits for months, or even years, as it often happens [32].

In the agrarian region of central Sweden, in the neighborhoods of Halmsjö, Broakulla, Timmernabben, Fågelfors, Mariannelund and Silvedalen a couple of immigrant entrepreneurs managed to restore small derelict stores, and in some 15 years established a network of dynamically operating small commercial facilities that brought life to the local area. Shops fulfilling basic functions - providing residents with food and household articles, have also become an important place for social interaction of residents and the owners themselves, and later, along with the development of the network, for people hired to work in the shops. The current success is the result of the hard work of the owners, their persistence and the ability to wait for deferred financial benefits.

The beginnings of the business in this particular case were associated with a 7-day work week, very often up to late evening hours from the early hours of the morning. Such organizational regime can prove a big challenge for potential entrepreneurs, and may become the primary factor verifying the success of an endeavor. The case presented here provides an illustration of a successful integration of immigrants who through hard work, perseverance and determination, apart from their own economic and psychological benefits (satisfaction from running their own business), brought to the local rural community a new experience regarding small entrepreneurship. Swedish villages and small towns have been dealing with the problem of depopulation for decades. The outflow of mainly young people from villages to cities brings many challenges. Additionally, the aging society of Sweden makes young people prefer to look for work and life among their peers, thus choosing large cities with dynamic high-tech industries. These trends, typical not only for Sweden, make villages and small towns deprived of young, energetic professionals. A prospective solution of this problem may be to encourage immigrants to settle down in agrarian areas and undertake work as self-employed individuals or as employees.

A similar example of integration based on the use of agrarian infrastructure is provided by a project entitled Mångfaldsmat Orust (Diversity Food Orust). The municipality of Orust and the authorities of the small town of Ellös (west coast of central Sweden) created favorable conditions for immigrant women to undertake a business venture by producing meals based on the traditions of the immigrants' country of origin while using local resources. It is worth noting that Ellös is a small town with about 1,000 inhabitants [33]. The village is known for its sailing yachts production, where mainly men are employed. With a relatively high number of immigrant residents (in 2016 there were 250 persons), finding employment by immigrant women became one of key challenges.

As practice shows, immigrant women have usually difficulties in integrating and taking up new jobs. Often, by staying at home and within their own ethnic culture, with time they become isolated and "separated" from society, which definitely disadvantages the individuals themselves and the whole society. Professional activation of women in classes in which they can realize their ambitions, skills or make use of their previous experience has become a characteristic feature of the modified integration policy of Sweden. The example of Ellös provides evidence that both parties - autochthons and newcomers - can mutually benefit, together working out solutions that are socially and economically productive. For the local economy, the project has brought the following benefits: a) new employees in the food and catering industry, b) increasing the use of products provided by local food producers, $c$ ) cultural enrichment of the indigenous community, d) activation of marginalized individuals or individuals with passive attitude towards community involvement (immigrant women from inter alia: Syria, Somalia, Ethiopia, Gambia and Nigeria), e) strengthening of contacts between Swedes and immigrants through jointly implemented projects, and last but not least f) improvement of the image of immigrants as people with entrepreneurial spirit, individuals resourceful and ready to contribute to the community's welfare. Exploiting the professional potential of immigrants, creating the conditions for its successful 
incorporation seems necessary to build and develop economic competitiveness not only of the region, but also of the entire country [34].

\subsubsection{Sport as a path to integration}

For young people, who are still in school, the possibility of integration with the host society is created by the school and other educational institutions as well as sports organizations. Sport provides many positive examples where integration can take place at an accelerated pace. Cooperation and competition based on mutual respect teach young people discipline, sensitivity to others talents, dispositions, differences. Sport teaches also perseverance, patience and coping with challenges.

Östra Ryds FI is an example of a successful project, initiated in 2014 in Östra Ryd, in the region of Östergötland (middle east Sweden). The idea was to create a youth football team to give boys 14-16 years of age the opportunity to pursue sports passion and to use the energy that young people of this age usually have. The initiative was enthusiastically received among male youth, both autochthons and immigrants. It turned out that prejudices, or reserves sometimes present among older generations, in this case did not occur. Confidence in the success of the project and youthful enthusiasm characterized the attitudes of young players, creating a multi-ethnic, multinational and multicultural team.

The first trainings seemed to be a metaphor for unsuccessful, uncoordinated cooperation. Misunderstandings on the pitch, however, did not move beyond its field. A team of trainers, consisting of autochthons and immigrants, was always of assistance providing professional support. The youth taking weekly trainings under the supervision of the trainers, in addition to sports competition, learned how to solve problems and deal with difficulties that could appear outside of the sport arena.

Transport turned out to be one of these kind of problems. The young players could easily arrive with the public transportation to the training sessions but returning home in the late evening was a substantial problem. It turned out, that public transport in Östra Ryd did not operate in the evenings when trainings usually ended. Maintaining of late evening public transportation in a small neighborhood of just 489 residents was too expensive.

The need to organize transport for young players, mobilized the local community to volunteer with private cars. Later, the Swedish church offered organizing transport for the youngsters. In this way, not only individuals, but also institutions present in the region joined the action which brought a positive effect for the integration of the whole community.

A similar example is provided by a joint action of several organizations in the northern part of Sweden: the Jämtland-Härjedalen Sport Society (Jämtland-Härjedalens Idrottsförbund), Primrose School of Swedish for Immigrants (Primrose SFI), Jemtland Innebandy and Jämtland-Härjedalen Innebandy society. The project called "Innebandy-projekt, Östersund" was addressed to immigrant women who wanted to learn how to play hockey - a popular sport discipline in the local area but mostly among men. The idea was to activate also girls and young women who attended Swedish language classes and were unemployed. However, being out of work was not a condition to join the sport team. The training sessions took place twice a week on a regular basis. The participants received professional equipment, professional theory background and professional support provided by experienced couches. The professional approach was a sign of relevance given to this kind of activity as a powerful and complementary element serving integration of the group with the local society [35]. The project in its pilot version lasted one year without any breaks for vacation or summer to keep the female team together and prevent drop-outs or potential discouragement of the attendees. After three months of joined indoor and outdoor trainings combined with theoretical sessions concerning physical, psychological and social aspects of sport, the group took part in a regional tournament. It was a crucial and important moment for the female players supported by the whole local community.

The project proved that sport activities approached seriously and professionally, backed with theory of physical activity, culture, values and society may help to facilitate and accelerate integration, especially of vulnerable groups like immigrant girls and women coming from non-European countries.

\section{CONCLUSIONS}

The Swedish integration policy towards immigrants consists of strategically developed actions, so that the continuously changing reality is managed in a long-term perspective, with effects benefiting the whole society and the economy. Tensions and turbulences present on international arena in recent decades, political, economic, religious and ethnic frictions, have launched a series of developments from 
which mass migration emerged as a sign of our times. The increasingly diverse societies (ethnically and culturally) pose many challenges, of which one seems to be particularly relevant for peaceful coexistence of groups and individuals and for the overall prosperity of the country. It is social cohesion.

Establishing social cohesion by management of diversity requires well-thought-out actions, effective mechanisms developed on the basis of practice and experience, and the courage to propose new solutions, which at first glance may even raise skepticism or negation. The examples of integration activities referenced in the text relate to a specific sphere of human existence, to proximity towards nature. Nature-based education seems to have a great potential, very often omitted in various integration strategies addressing immigrants. Paying more attention to this potential and adopting it for autochthons - immigrants out-door activities can indeed bring positive results. Kayaking, hiking, hill walking, discovering local fauna and flora, learning about the local products produced be local farmers, doing sport, etc. not only bring members of a community together, but also accelerate learning of the language by immigrants. As evidenced in practice this way of language acquisition can be more effective than the traditional SFI courses (Svenska för invandrare, Swedish for Immigrants) due to a high degree of participants engagement.

The modified integration policy of Sweden is a reaction to challenges like inter alia:

a) migration crisis of 2015 ,

b) aging society,

c) need to strengthen economic competitiveness,

d) depopulation of agrarian areas and areas economically marginalized, located away from large urban centers.

The challenges mentioned above are the subject of numerous national debates, public discourse and political campaigns. This was very visible during the Swedish parliamentary elections of 2018, in which the leaders of political parties, as well as the electoral programs dedicated much time to propose modification of the migration and integration policy [36]. Apart from the notion to make the SFI courses an obligation for all immigrants, the proposed measures included more restricted rules for integration. This meant that immigrants who declare their will to stay in Sweden, while fulfilling conditions required by law, would be obliged to actively undertake efforts to become well integrated into the Swedish society.

The set of integration activities using nature-based education seems in this context to soften the overall image of a much tougher Swedish integration policy for the years and decades to come. Particularly in the context of a future common Nordic project called "Norden 2040", that due to its complexity requires a separate discussion [37], [38], [39].

\section{ACKNOWLEDGEMENTS}

The findings of the paper are based on a research project financed by the National Science Centre, Poland, program OPUS 12, grant nr. 2016/23/B/HS5/00140.

\section{REFERENCES}

[1] Å. Nilsson, Efterkrigstidens invandring och utvandring, Örebro Statistiska Centralbyrån, 2004.

[2] L. Södergran, Svensk invandrar- och integrationspolitik, Umeå: Umeå University Press, 2000.

[3] M. Banaś, Swedish integration policy towards immigrants (Szwedzka polityka integracyjna wobec imigrantów), Kraków: Jagiellonian University Press, 2010.

[4] Statistik över invandringen 1980 -1997, www.immi.se/asyl/198097.htm

[5] Statistiska centalbyrån, www.scb.se

[6] https://www.economist.com/graphic-detail/2018/04/19/europeans-remain-welcoming-toimmigrants

[7] https://sweden.se/migration/the-refugee-challenge/

[8] https://www.scb.se/en/finding-statistics/statistics-by-subject-area/population/populationcomposition/population-statistics/pong/tables-and-graphs/yearly-statistics--the-wholecountry/summary-of-population-statistics/\#Fotnoter Proportion foreign-born in \%. 
[9] B. Parekh, "What is multiculturalism?" in Multiculturalism. A Symposium on Democracy in Culturally Diverse Societies, December 1999.

[10] P. West, Poverty of Multiculturalism, London: Civitas Institute, 2005.

[11] R. Phenninx, Integration Processes of Migrants in the European Union and policies relating to integration, Presentation for the Conference on Population Challenges, International Migration and Reproductive Health in Turkey and the European Union: Issues and Policy Implications, held in Istanbul, October 11/12, 2004.

[12] https://www.svt.se/nyheter/inrikes/sveriges-utsatta-omraden

[13] Nationella operativa avdelningen, Underrättelseenheten, Utsatta områden - Social ordning, kriminell struktur och utmaningar för polisen, 2017.

[14] https://www.bra.se/om-bra/nytt-fran-bra/arkiv/press/2018-03-27-slutlig-brottsstatistik-2017.html

[15] OECD, International Migration Division, Finding the Way: A Discussion of the Swedish Migrant Integration System, 2014.

[16] R. Konle -Seidl, Institute for Employment Research and European Parliament's Directorate General For Internal Policies, Policy Department A: Economic And Scientific Policy, Integration of Refugees in Austria, Germany and Sweden: Comparative Analysis, 2017.

[17] M. Banaś, Swedish integration policy towards immigrants (Szwedzka polityka integracyjna wobec imigrantów), Kraków: Jagiellonian University Press, 2010.

[18] K. Pitkänen, J. Oratuomi, D. Hellgren, E. Furman, S. Gentin, E. Sandberg, H. Øian, O. Krange, Nature-based integration Nordic experiences and examples, TemaNord 2017:517, 2017, p. 8.

[19] K. Pitkänen, J. Oratuomi, D. Hellgren, E. Furman, S. Gentin, E. Sandberg, H. Øian, O. Krange, Nature-based integration Nordic experiences and examples, TemaNord 2017:517, 2017, pp. 5-6.

[20] K. Pitkänen, J. Oratuomi, D. Hellgren, E. Furman, S. Gentin, E. Sandberg, H. Øian, O. Krange, Nature-based integration Nordic experiences and examples, TemaNord 2017:517, 2017, pp. 3538.

[21] S. Gentin, A. M. Chondromatidou, K. Pitkänen, A. Dolling, S. Præstholm, A. M. Pálsdóttir, Defining nature-based integration - perspectives and practices from the Nordic countries, Helsinki: Finnish Environment Institute (SYKE), 2018, p. 17.

[22] R. Phenninx, Integration Processes of Migrants in the European Union and policies relating to integration, Presentation for the Conference on Population Challenges, International Migration and Reproductive Health in Turkey and the European Union: Issues and Policy Implications, held in Istanbul, October 11/12, 2004.

[23] A. Grzymała - Kazłowska, "Integration - A Try of reconstructing of the concept"/ "Integracja próba rekonstrukcji pojęcia”, in Problemy integracji imigrantów (S. Łodziński, A. Grzymała Kazłowska, eds.), pp. 29-49, Warszawa: Warsaw University Press 2009.

[24] M. Banaś, Swedish integration policy towards immigrants (Szwedzka polityka integracyjna wobec imigrantów), Kraków: Jagiellonian University Press, 2010, pp. 40-43.

[25] H. Esser, Soziologie: Spezielle Grundlagen, Frankfurt am Main: Campus-Verlag, 1999.

[26] S. Gentin, A. M. Chondromatidou, K. Pitkänen, A. Dolling, S. Præstholm, A. M. Pálsdóttir, Defining nature-based integration - perspectives and practices from the Nordic countries, Helsinki: Finnish Environment Institute (SYKE), 2018.

[27] S. Gentin, A. M. Chondromatidou, K. Pitkänen, A. Dolling, S. Præstholm, A. M. Pálsdóttir, Defining nature-based integration - perspectives and practices from the Nordic countries, Helsinki: Finnish Environment Institute (SYKE), 2018, p. 44.

[28] http://www.meny.se/nyanlanda/Skog/index. html.

[29] K. Pitkänen, J. Oratuomi, D. Hellgren, E. Furman, S. Gentin, E. Sandberg, H. Øian, O. Krange, Nature-based integration Nordic experiences and examples, TemaNord 2017:517, 2017, p. 49.

[30] http://hushallningssallskapet.se/kurser-utbildningar/. 
[31] K. Pitkänen, J. Oratuomi, D. Hellgren, E. Furman, S. Gentin, E. Sandberg, H. Øian, O. Krange, Nature-based integration Nordic experiences and examples, TemaNord 2017:517, 2017, p. 49.

[32] J. Hydén, De motar butiksdöden på landsbygden, Stockholm: Landsbygdsnätverket, 2018.

[33] Statistiska centralbyrån 2017.

[34] Tillväxtverket, Snabbare integration genom företagande och sysselsättning - en studie av Tillväxtverkets satsning på förstudier och pilotprojekt för snabbare integration, Raport 0213, Tillväxtverket 2017.

[35] http://www.jhidrott.rf.se/varanyheter/2017/innebandy-projektostersund/.

[36] M. Banaś, "Culture, Migration-Integration, and Political Discourse" in Experience of Otherness Political Identity and its Reflection in Culture, Literature, Translation and Humanities, (J. Javorčíková, E. Höhn, eds.), pp. 18 - 32, Bratislava: Univerzita Mateja Bela and Z-F LINGUA, 2018.

[37] M. Banaś, "On a Pan - Nordic Project in 2040" /,O pewnym pannordyckim projekcie i roku 2040" in On theoretical and practical issues of political culture / Teoretyczne i praktyczne problemy kultury politycznej, (M. Banaś ed.), pp. 79 - 91, Cracow: Księgarnia Akademicka, 2013.

[38] M, Banaś, "Migration in the Nordic political discourse. Towards a revised approach" in Roczniki Nauk Społecznych, (A. Szabaciuk ed.), pp. 31 - 48, Vol. 3, Lublin: Katolicki Uniwersytet Lubelski, 2014.

[39] M. Banaś, "Nordic Federation as a State" in European Economic Integration and Convergence, "Rocznik Instytutu Europy Środkowo-Wschodniej", (B. Jóźwik, T. Stępniewski, eds.), pp. 129 143, Lublin: Institute of East-Central Europe, 2012. 